\title{
Policy Recommendation for Educational Management to Promote Occupations in the Community Learning Centers for Non-Formal and Informal Education
}

\author{
Hataikan Soyngam ${ }^{1}$, Wallapha Ariratana ${ }^{1} \&$ Dawruwan Thawinkarn ${ }^{1}$ \\ ${ }^{1}$ Department of Educational Administration, Faculty of Education, Khon Kaen University, Thailand \\ Correspondence: Wallapha Ariratana, Department of Educational Administration, Faculty of Education, Khon \\ Kaen 40002, Thailand. Tel: 66-81-8179200. E-mail: wallapha@kku.ac.th
}

Received: June 6, 2021; Accepted: June 22, 2021; Published: June 23, 2021

\begin{abstract}
This study was planned to investigate the current and desirable conditions of educational management to promote occupations in the community learning centers for non-formal and informal education using needs assessments. A sum of 423 respondents encompassed 184 school administrators and 239 teachers participated in the survey using a stratified random sampling method. A questionnaire consisted of 47 items was used as the research instrument. Data were analyzed using mean scores, standard deviation, and priority needs index modified. The study results showed that the overall current state was at a high level (mean score $=3.53$ ) while the desirable condition was at the highest level (mean score $=4.41$ ), respectively, for educational management to promote occupations in the community learning centers for non-formal and informal education. Finally, the needs assessment results indicated that the highest priority was the change management factor $\left(\mathrm{PNI}_{\text {modified }}=0.403\right)$, followed by curriculum development and learning activities in promoting occupations factor $\left(\mathrm{PNI}_{\text {modified }}=0.254\right)$, promotion of educational partners' networking factor $\left(\mathrm{PNI}_{\text {modified }}=0.247\right)$, and being a lifelong learner factor $\left(\mathrm{PNI}_{\text {modified }}=0.206\right)$. The lowest priority index of needs was digital literacy for occupations $\left(\mathrm{PNI}_{\text {modified }}=0.161\right)$. The results contribute significantly to knowledge with regard to needs assessments which will be the reference for educational managers and teachers to understand how to promote occupational education.
\end{abstract}

Keywords: community learning center, educational management, informal education, needs assessments, nonformal education, occupation

\section{Introduction}

The community learning center (CLC) has been launched by the United Nations Educational, Scientific and Cultural Organization (UNESCO) aiming to generate grassroots-based interest and involvement in learning and continuing education, particularly for those disadvantaged and poor people within the framework of the AsiaPacific Program of Education for All (APPEAL) starting from 1998 (UNESCO office Bangkok and Regional Bureau for Education in Asia and the Pacific, 2008). Moreover, the creation of CLCs for non-formal and informal educational program provides academic enrichment opportunities for students, particularly those students from high-poverty and low-performing schools. Therefore, the program assists students in meeting educational standards in core academic subjects, such as reading and mathematics to upgrade their occupational knowledge and skills (Martiskainen, 2017). Besides, the program offers students a broad array of enrichment activities that can complement their regular academic programs, so-called formal educational program. In United States of America, the CLCs for non-formal and informal educational program offers literacy and other educational services to the families of participating students (U.S. Department of Education, 2018).

The CLC is defined as a local educational institution organized by local people to provide various learning opportunities beyond the formal education system, so-called non-formal or informal education (Non-formal Education Commission ONFEC, 2005). In 2000, the CLCs were launched in Thailand with support from both UNESCO APPEAL and the United Nations Development Program. The CLCs in Thailand are categorized into two different operations, for example, operated or organized by local people with some support from the government. According to the record of ONFEC (2005), a total of 8,057 CLCs were established in 76 provinces located in six regions of Thailand. They are 1665, 3325, 1152, 1127, 490, and 298 in northern, northeastern, central, southern, western, metropolitan Bangkok, respectively. This reflects that CLCs have expanded speedily with diverse settings, structures, and activities. 
The establishment of CLCs is aimed to elevate human advancement by offering opportunities for lifelong learning to the local community. Empowerment, social transformation, and quality of life improvement of the local community are the CLCs' main concerns. Therefore, the educational managers of CLCs play their key functions to provide the following activities, namely education and training, community information and resource services, community development activities, and coordination and networking. Moreover, local problems and needs to develop occupational skills have to take into account when educational managers of CLCs are planning their main activities that are related to basic learning and other developmental activities so that these activities will be in line with the readiness and context of the local community.

The community management is different from the classical notion of management being about educational managers can ask, persuade, and influence subordinates to carry out their tasks according to their demands (Sullivan, 2007: 142). However, community management in turn is usually less hierarchy (Onyx \& Leonard, 2011), often based on volunteer action (Zanbar \& Itzhaky, 2013), involving the creation of social capital (Riley, 2012), and acting as a symbolism for change (Sullivan, 2007). As a result, educational managers of CLCs are informal, non-elected managers (Bénit-Gbaffou \& Katsaura, 2014). In this line of reasoning, CLC's educational managers should understand their needs to administer the non-formal and informal education because their leadership should be seen not only as position and authority but also as an emergent interactive dynamic (Uhl-Bien, Marion, \& McKelvey, 2007). Uhl-Bien et al. further identified three types of leadership are required for CLC's educational managers as follows: (i) administrative leadership is hierarchical and controlling; (ii) enabling leadership encourages creative problem-solving, learning and adaptability, and (iii) adaptive leadership is a dynamic that empowers change (Uhl-Bien et al., 2007: 299).

Needs assessment is important in the human resource development field because it can help the educational managers of educational institutions including CLCs to plan the instructional design process for any training or educational initiative to be successful. According to Pilcher (2016), need assessment is no longer viewed as a primary step within the instructional design process but rather as a broader analysis of performance problems and how the performance problems can be solved. Hence, need assessment has allowed educational managers to see it as a more holistic, systematic viewpoint and can be used in the human resources domain (Pilcher, 2016). According to the literature review above, the researchers conceptualized the essential components of educational management that related to promote occupations into five components, namely, change management, curriculum development and learning activities in promoting careers, promotion of educational partners' networking, being a lifelong learner, and digital literacy for a career. These five components have been proposed by the Office of the Promotion of Non-formal and Informal Education (2012) in order to develop a new management system for CLCs to work collaboratively thus being the best practice institutions. In this line of reasoning, the researchers aimed to investigate the current and desirable conditions of educational management to promote occupations in the CLCs for non-formal and informal education using needs assessments. This is followed by aiming to explore the need assessments of each component of the educational management in promoting occupations.

\section{Method}

\subsection{Samples and Sampling Method}

A stratified random sampling method was employed to select samples from a population consists of educational managers and teachers from the office of non-formal and informal education of 20 provincial centers located in the northeast of Thailand. A total of 423 samples were selected using Krejcie and Morgan's (1970) sample size formula. The researchers divided the population into educational manager and teacher categories and randomly selected 184 and 239 samples from the educational manager and teacher categories, respectively.

\subsection{Research Design and Instrument}

A five-scale rating survey questionnaire consisted of 47 items was employed as a technique of assembling quantitative data. A survey research design was found appropriate for this study as researchers designed a quality need assessment of educational management indicators to promote occupations. Besides the four-factor demographics of respondents were collected, the other sections of the questionnaire were used to survey the need assessment of five vital factors of educational management to promote occupations, namely, change management (14 items), curriculum development and learning activities in promoting occupations (10 items), promotion of educational partners' networking (6 items), being a lifelong learner (6 items), and digital literacy for occupations (6 items). 


\subsection{Pilot Study, Data Collection, and Data Analysis}

The preliminary research was conducted on five experts for the purpose of identifying the essential factors and indicators of education management to promote occupations. The preliminary results were conducted with regard to fitting the 17 educational management indicators with the five vital factors corresponding to the Thai context. All experts decided to use the mean score of 3.00 or more as a cut-off point, and the coefficient of diffusion as 20 percent or less, in order to blend those factors on the grounding of the current study on educational management to promote occupations. Table 1 exhibits the details of the essential factors and indicators of educational management to promote occupations.

Table 1. Educational Management Factors and Indicators to Promote Occupations

\begin{tabular}{|c|c|c|}
\hline Factors & $\begin{array}{l}\text { No of } \\
\text { indicator }\end{array}$ & Indicators \\
\hline Change management & 4 & $\begin{array}{l}\text { Creating a vision of change } \\
\text { Encouraging leaders for change } \\
\text { Learning new things } \\
\text { Motivation and participation }\end{array}$ \\
\hline $\begin{array}{l}\text { Curriculum development } \\
\text { and learning activities in } \\
\text { promoting occupations }\end{array}$ & 4 & $\begin{array}{l}\text { Needs and necessities of promoting occupations } \\
\text { Curriculum development to promote occupations } \\
\text { Organizing learning activities for occupations } \\
\text { Assessment of courses and learning development }\end{array}$ \\
\hline $\begin{array}{l}\text { Promotion of educational } \\
\text { partners' networking }\end{array}$ & 3 & $\begin{array}{l}\text { Collaborating with others for joint development } \\
\text { Setting common goals } \\
\text { Exchange ideas through activities }\end{array}$ \\
\hline Being a lifelong learner & 3 & $\begin{array}{l}\text { Self-seeking in occupations } \\
\text { Applying learned knowledge in occupations. } \\
\text { Problem-solving and occupational development }\end{array}$ \\
\hline $\begin{array}{l}\text { Digital literacy for } \\
\text { occupations }\end{array}$ & 3 & $\begin{array}{l}\text { Understanding the importance of digital literacy } \\
\text { Using digital technology for occupational development } \\
\text { Evaluating the use of digital in occupations }\end{array}$ \\
\hline
\end{tabular}

The researchers then carried out the pilot study to assess the reliability of the questionnaire to 30 panels including 10 educational managers and 20 teachers who were excluded from the samples of the actual study. The reliability values were found at the range of acceptable to good levels as shown in Table 2.

Table 2. Reliability Values for Educational Management Factors to Promote Occupations

\begin{tabular}{lcc}
\hline \multicolumn{1}{c}{ Factors } & $\begin{array}{c}\text { Cronbach alpha } \\
\text { values }\end{array}$ & Interpretation \\
\hline $\begin{array}{l}\text { Change management } \\
\text { Curriculum development and learning activities in promoting }\end{array}$ & 0.745 & Acceptable \\
$\begin{array}{l}\text { occupations } \\
\text { Promotion of educational partners' networking }\end{array}$ & 0.852 & Good \\
$\begin{array}{l}\text { Being a lifelong learner } \\
\text { Digital literacy for occupations }\end{array}$ & 0.815 & Good \\
\hline \multicolumn{1}{c}{ Overall } & 0.807 & Good \\
& 0.731 & Acceptable \\
\hline
\end{tabular}

The collected data were intended to explore the need assessments of educational management to promote occupations through non-formal and informal education in CLCs. PNI modification calculation was utilized to determine the disparity of needs assessments between the current conditions compared with the desired conditions. The indication of the needs assessment of educational management components is taken into account by the PNI index of at least .30. In other words, the educational management factors are more crucial if the PNI index is higher than .30. Therefore, the obtained data imposes the essential factors of educational management that are needed for the occupational development of a CLC using this formula: $\mathrm{PNI}_{\text {modified }}=(1-\mathrm{D}) / \mathrm{D}$ 
On the other hand, mean scores and standard deviations were used as representative of the data. The mean score was very useful for researchers to understand the raw data that fell under a normal curve before researchers decided to have similar means when repeated samples were drawn from the same population. This assists the researchers to arrange and interpret according to the obtained values. Meanwhile, the standard deviation was used as an index of variability of the data distribution.

\section{Results}

\subsection{General Profile of Respondents}

There were 184 educational managers and 239 teachers who participated in this study, giving a total of 423 respondents. The gender representation was quite equal as 41.6 percent are males and 58.4 percent are females. Besides, the selected respondents were forming an equal distribution of age groups. For example, 27.0, 30.0, and 24.1 percent of them were from the age range as 31 to 40 years old, 41 to 50 years old, and more than 51 years old. However, most of them were having five to 10 years of working experience. On top of that, the majority of them have their highest academic qualification as a bachelor's or a master's degree respectively, giving a total of 97.4 percent. Table 1 displays the general profile of the respondents.

Table 3. Distribution of the Respondents

\begin{tabular}{lll}
\hline General Profile & Frequency & Percent \\
\hline Gender & & \\
\hline Male & 176 & 41.6 \\
Female & 247 & 58.4 \\
\hline Age & & \\
\hline$<30$ years old & 80 & 18.9 \\
31 to 40 years old & 114 & 27.0 \\
41 to 50 years old & 127 & 30.0 \\
$>50$ years old & 102 & 24.1 \\
\hline Years of experience & & \\
\hline$<5$ years & 102 & 24.1 \\
5 to 10 years & 255 & 60.3 \\
$>10$ years & 66 & 15.6 \\
\hline Highest academic qualification & & \\
\hline Bachelor's degree & 200 & 47.3 \\
Master's degree & 212 & 50.1 \\
Doctoral degree & 11 & 2.6 \\
\hline
\end{tabular}

\subsection{Need Assessments of Educational Management to Promote Occupations in CLCs}

The interpretation of the mean value of each factor of educational management to promote occupations in CLCs was evaluated in parallel to Boomchom's (2014) identification as shown in Table 4.

Table 4. Interpretation of Educational Management Factors

\begin{tabular}{cc}
\hline Interval of Mean Value & Interpretation \\
\hline $4.51-5.00$ & Highest \\
$3.51-4.50$ & High \\
$2.51-3.50$ & Moderate \\
$1.51-2.50$ & Low \\
$1.00-1.50$ & Lowest \\
\hline
\end{tabular}

Table 5 illustrates the overall current state of educational management to promote occupations in CLCs for nonformal and informal education was found at high level $(\overline{\mathrm{X}}=3.53, S D=0.96)$. The digital literacy for occupations factor was found to have highest needs level $(\overline{\mathrm{X}}=3.80, S D=0.99)$. This is followed by being a lifelong learner factor $(\overline{\mathrm{X}}=3.69, S D=0.77)$, promotion of educational partners' networking factor $(\overline{\mathrm{X}}=3.52, S D=0.98)$, and curriculum development and learning activities in promoting occupations factor $(\overline{\mathrm{X}}=3.51, S D=0.99)$. The lowest current condition was change management factor $(\overline{\mathrm{X}}=3.13, S D=0.99)$. 
On the other hand, results showed that the overall desirable condition of educational management to promote occupations in the CLCs for non-formal and informal education was at the highest level $(\overline{\mathrm{X}}=4.41, S D=0.63)$. The factor of being a lifelong learner has the highest needs level $(\overline{\mathrm{X}}=4.45, S D=0.61)$. This is continued with digital literacy for occupations factor $(\overline{\mathrm{X}}=4.41, S D=0.63)$ and curriculum development and learning activities in promoting occupations factor $(\overline{\mathrm{X}}=4.40, S D=0.64)$. The factors of change management and promotion of educational partners' networking were having the same needs level $(\overline{\mathrm{X}}=4.39, S D=0.65)$ and $(\overline{\mathrm{X}}=4.39, S D=0.64)$, respectively.

The results of the need assessments of educational management to promote occupations in CLCs in terms of nonformal and informal education showed that change management factor is the essential factor of educational management to promote occupations through non-formal and informal educational implementation in CLCs $\left(\mathrm{PNI}_{\text {modified }}=0.403\right)$. This is followed by the curriculum development and learning activities in promoting occupations factor $\left(\mathrm{PNI}_{\text {modified }}=0.254\right)$, promotion of educational partners' networking factor $\left(\mathrm{PNI}_{\text {modified }}=0.247\right)$ and being a lifelong learner factor $\left(\mathrm{PNI}_{\text {modified }}=0.206\right)$. However, the least capacity factor was digital literacy for occupations ( $\mathrm{PNI}_{\text {modified }}=0.161$ ). Table 5 portrays the details of each factor of educational management to promote occupations in CLCs ranking in order from the most needed to the least needed.

Table 5. Overall Needs Assessment Index of Educational Management to Promote Occupations on CLCs

\begin{tabular}{|c|c|c|c|c|c|c|}
\hline \multirow[t]{2}{*}{$\begin{array}{l}\text { Educational management components to promote } \\
\text { occupations }\end{array}$} & \multicolumn{2}{|c|}{$\begin{array}{l}\text { Current } \\
\text { conditions }\end{array}$} & \multicolumn{2}{|c|}{$\begin{array}{l}\text { Desirable } \\
\text { conditions }\end{array}$} & \multirow[t]{2}{*}{$\mathrm{PNI}_{\text {modified }}$} & \multirow[t]{2}{*}{ Ranking } \\
\hline & $\overline{\mathrm{X}}$ & $S D$ & $\overline{\mathrm{X}}$ & $S D$ & & \\
\hline Change management & 3.13 & 0.99 & 4.39 & 0.65 & 0.403 & 1 \\
\hline $\begin{array}{l}\text { Curriculum development and learning activities in } \\
\text { promoting occupations }\end{array}$ & 3.51 & 0.99 & 4.40 & 0.64 & 0.254 & 2 \\
\hline Promotion of educational partners' networking & 3.52 & 0.98 & 4.39 & 0.64 & 0.247 & 3 \\
\hline Being a lifelong learner & 3.69 & 0.77 & 4.45 & 0.61 & 0.206 & 4 \\
\hline Digital literacy for occupations & 3.80 & 0.99 & 4.41 & 0.63 & 0.161 & 5 \\
\hline Total & 3.53 & 0.96 & 4.41 & 0.63 & & \\
\hline
\end{tabular}

\subsection{Needs Assessments of Change Management Factor}

The change management factor was explored in detail as portrayed in Table 6 . The greatest gap between the current condition and desirable condition in terms of change management revealed that CLCs have to exchange information internally and externally through various forms of communication about occupational development. Table 6 illustrates the 14 gaps in descending order between the current conditions and the desirable conditions for the change management factor.

Table 6. Needs Assessment Index of Change Management Factor

\begin{tabular}{lccccccc}
\hline Change management & \multicolumn{2}{l}{$\begin{array}{l}\text { Current } \\
\text { conditions }\end{array}$} & \multicolumn{2}{l}{$\begin{array}{l}\text { Desirable } \\
\text { conditions }\end{array}$} & \multirow{2}{*}{ PNI $_{\text {modified }}$} & Ranking \\
\cline { 2 - 5 } & $\overline{\mathrm{X}}$ & $S D$ & $\overline{\mathrm{X}}$ & $S D$ & & \\
\hline $\begin{array}{l}\text { CLC exchanges information internally and externally } \\
\text { through various forms of communication about } \\
\text { occupational development. }\end{array}$ & 2.95 & 0.56 & 4.31 & 0.72 & 0.461 & 1 \\
\hline $\begin{array}{l}\text { CLC develops leadership skills for occupational } \\
\text { development. }\end{array}$ & 3.00 & 1.26 & 4.38 & 0.64 & 0.460 & 2 \\
\hline CLC provides a platform for occupation success. & 3.03 & 0.83 & 4.42 & 0.64 & 0.459 & 3 \\
\hline $\begin{array}{l}\text { CLC creates innovations and mobilizes resources } \\
\text { about occupations. }\end{array}$ & 3.07 & 1.06 & 4.48 & 0.58 & 0.458 & 4 \\
\hline $\begin{array}{l}\text { CLC organizes activities to promote occupations in the } \\
\text { community. }\end{array}$ & 2.97 & 1.24 & 4.33 & 0.67 & 0.456 & 5 \\
\hline $\begin{array}{l}\text { CLC creates vocational learning communities for } \\
\text { knowledge exchange. }\end{array}$ & 3.02 & 1.26 & 4.40 & 0.65 & 0.456 & 6 \\
\hline CLC encourages team participation. & 2.99 & 0.70 & 4.33 & 0.74 & 0.450 & 7 \\
\hline CLC set a work scope for team members to work & 3.00 & 0.68 & 4.32 & 0.70 & 0.441 & 8 \\
\hline
\end{tabular}




\begin{tabular}{llllllll}
\hline together. & & & & & & \\
\hline $\begin{array}{l}\text { CLC formulates strategies and work plans of projects, } \\
\text { implements, monitors, and evaluates systematically. }\end{array}$ & 0.13 & 0.37 & 0.68 & 0.399 & 9 \\
\hline $\begin{array}{l}\text { CLC listens to suggestions for motivation and goal } \\
\text { achievement. }\end{array}$ & 3.23 & 1.27 & 4.43 & 0.62 & 0.369 & 10 \\
\hline $\begin{array}{l}\text { CLC provides new knowledge and skills to create } \\
\text { innovative thinking. }\end{array}$ & 3.16 & 1.20 & 4.32 & 0.65 & 0.366 & 11 \\
\hline $\begin{array}{l}\text { CLC holds meetings to raise awareness and } \\
\text { understanding of change. }\end{array}$ & 3.35 & 0.60 & 4.48 & 0.59 & 0.334 & 12 \\
\hline $\begin{array}{l}\text { CLC set goals, visions, and mission about occupations } \\
\text { together with communities. }\end{array}$ & 3.35 & 1.15 & 4.44 & 0.65 & 0.326 & 13 \\
\hline CLC organizes contests to promote new products. & 3.56 & 1.23 & 4.48 & 0.61 & 0.260 & 14 \\
\hline Total & 3.13 & 0.99 & 4.39 & 0.65 & & \\
\hline
\end{tabular}

\subsection{Needs Assessments of Curriculum Development and Learning Activities in Promoting Occupations Factor}

The next factor was the curriculum development and learning activities in promoting occupations. The greatest gap between the current condition and desirable condition in the curriculum development and learning activities in promoting occupations indicated that CLC utilizes the results of the needs survey to create an occupational curriculum. Table 7 demonstrates the 10 gaps in descending order between the current conditions and the desirable conditions for the curriculum development and learning activities in promoting occupations.

Table 7. Needs Assessment Index of Curriculum Development and Learning Activities in Promoting Occupations Factor

\begin{tabular}{|c|c|c|c|c|c|c|}
\hline \multirow[t]{2}{*}{$\begin{array}{l}\text { Curriculum development and learning activities in } \\
\text { promoting occupations }\end{array}$} & \multicolumn{2}{|c|}{$\begin{array}{l}\text { Current } \\
\text { conditions }\end{array}$} & \multicolumn{2}{|c|}{$\begin{array}{l}\text { Desirable } \\
\text { conditions }\end{array}$} & \multirow[t]{2}{*}{$\mathrm{PNI}_{\text {modified }}$} & \multirow[t]{2}{*}{ Ranking } \\
\hline & $\overline{\mathrm{X}}$ & $S D$ & $\overline{\mathrm{X}}$ & $S D$ & & \\
\hline $\begin{array}{l}\text { CLC utilizes the results of the needs survey to create } \\
\text { an occupational curriculum. }\end{array}$ & 3.26 & 0.92 & 4.35 & 0.69 & 0.334 & 1 \\
\hline $\begin{array}{l}\text { CLC studies basic information and problems about } \\
\text { community context to correspond to the community's } \\
\text { needs. }\end{array}$ & 3.29 & 0.95 & 4.30 & 0.70 & 0.308 & 2 \\
\hline $\begin{array}{l}\text { Teachers are encouraged to assess student progress to } \\
\text { create various evaluation tools. }\end{array}$ & 3.39 & 0.98 & 4.43 & 0.63 & 0.307 & 3 \\
\hline $\begin{array}{l}\text { Learning programs are consistent with students' real- } \\
\text { life and matching students' interests. }\end{array}$ & 3.46 & 0.99 & 4.39 & 0.63 & 0.269 & 4 \\
\hline $\begin{array}{l}\text { CLC creates occupational courses to develop } \\
\text { professional skills. }\end{array}$ & 3.51 & 1.00 & 4.42 & 0.61 & 0.258 & 5 \\
\hline $\begin{array}{l}\text { Various courses that promoting occupations } \\
\text { according to policies and needs }\end{array}$ & 3.52 & 0.97 & 4.40 & 0.64 & 0.252 & 6 \\
\hline $\begin{array}{l}\text { CLC organizes learning activities that promoting } \\
\text { systematic thinking. }\end{array}$ & 3.61 & 0.96 & 4.44 & 0.62 & 0.231 & 7 \\
\hline $\begin{array}{l}\text { CLC promotes learning experiences according to } \\
\text { sufficiency economy philosophy. }\end{array}$ & 3.62 & 1.06 & 4.40 & 0.66 & 0.216 & 8 \\
\hline $\begin{array}{l}\text { CLC organizes activities to develop various learning } \\
\text { networks. }\end{array}$ & 3.68 & 1.06 & 4.43 & 0.62 & 0.202 & 9 \\
\hline $\begin{array}{l}\text { CLC supervises, monitors, evaluates, and reflects } \\
\text { continuously for improvement. }\end{array}$ & 3.73 & 1.02 & 4.39 & 0.64 & 0.180 & 10 \\
\hline Total & 3.51 & 0.99 & 4.40 & 0.64 & & \\
\hline
\end{tabular}

\subsection{Needs Assessments of Promotion of Educational Partners' Networking Factor}

The following factor of educational management to discuss was the promotion of educational partners' networking. Table 8 illustrates the six greatest gaps between the current conditions and the desirable conditions for the promotion of educational partners' networking. 
Table 8. Needs Assessment Index of Promotion of Educational Partners' Networking Factor

\begin{tabular}{|c|c|c|c|c|c|c|}
\hline \multirow[t]{2}{*}{ Promotion of educational partners' networking } & \multicolumn{2}{|c|}{$\begin{array}{l}\text { Current } \\
\text { conditions }\end{array}$} & \multicolumn{2}{|c|}{$\begin{array}{l}\text { Desirable } \\
\text { conditions }\end{array}$} & \multirow[t]{2}{*}{$\mathrm{PNI}_{\text {modified }}$} & \multirow[t]{2}{*}{ Ranking } \\
\hline & $\overline{\bar{X}}$ & $S D$ & $\overline{\mathrm{X}}$ & $S D$ & & \\
\hline $\begin{array}{l}\text { Cooperation with external institutions to set goals in } \\
\text { providing occupational knowledge and advice. }\end{array}$ & 3.43 & 1.05 & 4.43 & 0.64 & 0.293 & 1 \\
\hline $\begin{array}{l}\text { CLC organizes academic meetings for delivering } \\
\text { occupational enhancements. }\end{array}$ & 3.44 & 1.04 & 4.39 & 0.65 & 0.275 & 2 \\
\hline $\begin{array}{l}\text { Students are encouraged for positive participation in } \\
\text { learning activities. }\end{array}$ & 3.59 & 1.09 & 4.40 & 0.58 & 0.250 & 3 \\
\hline $\begin{array}{l}\text { CLC provides training and seminars for vocational } \\
\text { knowledge exchange. }\end{array}$ & 3.55 & 1.07 & 4.39 & 0.65 & 0.236 & 4 \\
\hline $\begin{array}{l}\text { Cooperation with external institutions in providing } \\
\text { occupational education. }\end{array}$ & 3.59 & 1.04 & 4.36 & 0.66 & 0.214 & 5 \\
\hline $\begin{array}{l}\text { CLC plans and collects data jointly with network } \\
\text { partners to educate the community. }\end{array}$ & 3.60 & 1.06 & 4.37 & 0.66 & 0.214 & 6 \\
\hline Total & 3.52 & 1.06 & 4.39 & 0.64 & & \\
\hline
\end{tabular}

\subsection{Needs Assessments of Being a Lifelong Learner Factor}

The subsequent factor to the debate was being a lifelong learner. Table 9 shows the six greatest gaps between the current conditions and the desirable conditions for being a lifelong learner.

Table 9. Needs Assessment Index of Being a Lifelong Learner Factor

\begin{tabular}{|c|c|c|c|c|c|c|}
\hline \multirow[t]{2}{*}{ Being a lifelong learner } & \multicolumn{2}{|c|}{$\begin{array}{l}\text { Current } \\
\text { conditions }\end{array}$} & \multicolumn{2}{|c|}{$\begin{array}{l}\text { Desirable } \\
\text { conditions }\end{array}$} & \multirow[t]{2}{*}{$\mathrm{PNI}_{\text {modified }}$} & \multirow[t]{2}{*}{ Ranking } \\
\hline & $\overline{\mathrm{X}}$ & $S D$ & $\overline{\mathrm{X}}$ & $S D$ & & \\
\hline $\begin{array}{l}\text { CLC creates a knowledge exchange learning } \\
\text { network for professional development. }\end{array}$ & 3.62 & 0.79 & 4.45 & 0.59 & 0.229 & 1 \\
\hline $\begin{array}{l}\text { Students are encouraged to apply knowledge from } \\
\text { local wisdom for new occupations. }\end{array}$ & 3.65 & 0.80 & 4.47 & 0.60 & 0.226 & 2 \\
\hline $\begin{array}{l}\text { Students are encouraged to reflect, solve problems, } \\
\text { and develop innovations. }\end{array}$ & 3.67 & 0.74 & 4.43 & 0.61 & 0.207 & 3 \\
\hline $\begin{array}{l}\text { Various occupational courses online training is } \\
\text { provided. }\end{array}$ & 3.73 & 0.85 & 4.43 & 0.62 & 0.189 & 4 \\
\hline $\begin{array}{l}\text { Basic internet network to support students for } \\
\text { accessing occupational resources. }\end{array}$ & 3.77 & 0.68 & 4.44 & 0.63 & 0.177 & 5 \\
\hline $\begin{array}{l}\text { Students are encouraged to develop new } \\
\text { knowledge for transmitting commercially. }\end{array}$ & 3.70 & 0.75 & 4.47 & 0.59 & 0.104 & 6 \\
\hline Total & 3.69 & 0.77 & 4.45 & 0.61 & & \\
\hline
\end{tabular}

\subsection{Needs Assessments of Digital Literacy for Occupations Factor}

The final factor to deliberate was digital literacy for occupations. Table 10 displays the six greatest gaps between the current conditions and the desirable conditions for digital literacy for occupations.

Table 10. Needs Assessment Index of Digital Literacy for Occupations Factor

\begin{tabular}{|c|c|c|c|c|c|c|}
\hline \multirow[t]{2}{*}{ Digital literacy for occupations } & \multicolumn{2}{|c|}{$\begin{array}{l}\text { Current } \\
\text { conditions }\end{array}$} & \multicolumn{2}{|c|}{$\begin{array}{l}\text { Desirable } \\
\text { conditions }\end{array}$} & \multirow[t]{2}{*}{$\mathrm{PNI}_{\text {modified }}$} & \multirow[t]{2}{*}{ Ranking } \\
\hline & $\overline{\mathrm{X}}$ & $S D$ & $\overline{\mathrm{X}}$ & $S D$ & & \\
\hline $\begin{array}{l}\text { CLC provides knowledge management to exhibits } \\
\text { products for online sales. }\end{array}$ & 3.65 & 1.02 & 4.40 & 0.65 & 0.203 & 1 \\
\hline Students are encouraged to possess digital & 3.80 & 1.00 & 4.46 & 0.58 & 0.174 & 2 \\
\hline
\end{tabular}




\begin{tabular}{|c|c|c|c|c|c|c|}
\hline $\begin{array}{l}\text { CLC organizes contests in creating packaging } \\
\text { logos, webpage, and online sales. }\end{array}$ & 3.76 & 1.01 & 4.38 & 0.67 & 0.163 & 3 \\
\hline $\begin{array}{l}\text { Open online channels in promoting occupations } \\
\text { related to digital technology. }\end{array}$ & 3.82 & 1.03 & 4.41 & 0.62 & 0.156 & 4 \\
\hline $\begin{array}{l}\text { Various inputs to develop students' digital literacy } \\
\text { in online channels. }\end{array}$ & 3.84 & 1.00 & 4.41 & 0.60 & 0.147 & 5 \\
\hline $\begin{array}{l}\text { CLC develops students' technological and } \\
\text { innovative skills for occupations. }\end{array}$ & 3.91 & 0.96 & 4.41 & 0.63 & 0.128 & 6 \\
\hline Total & 3.80 & 1.00 & 4.41 & 0.63 & & \\
\hline
\end{tabular}

\section{Discussion}

The results of needs assessments to investigate the current and desirable conditions of educational management to promote occupations in the CLCs for non-formal and informal education gained recognition as an essential step within the instructional design process in the human resource development field. Besides, the study outcomes have successfully recommended to the non-formal and informal educational program planners and developers to consider the results of needs assessment as a crucial first step for any training or educational initiative to promote occupations in the future. As a result, needs assessments are no longer viewed primarily as a step within the instructional design process, but rather as a broader analysis of performance problems and how they can be solved. (Berger, n.d.). This perspective has allowed educational managers of CLCs to see needs assessment from a more holistic and systemic viewpoint in promoting occupations through non-formal and informal education as the implications of this study.

On this line of reasoning, the needs assessment results of this study provide clear direction and focus for the educational managers of CLCs to promote occupational education in the context of organizational performance. In this line of reasoning, these comprehensive needs assessments have successfully provided a systematic way to plan strategically for promoting non-formal and informal occupational education. In simple terms, educational managers are recommended to focus on the five essential factors, namely, change management, curriculum development and learning activities in promoting occupations, promotion of educational partners' networking, being a lifelong learner, and digital literacy for occupations in order to close the gap.

\section{Acknowledgments}

The authors gratefully acknowledge the use of service and facilities of the Faculty of Education, Khon Kaen University, Khon Kaen 40002, Thailand. The contents of this manuscript are derived from the first author's doctoral dissertation thus fulfilling the Ph.D. requirement of Khon Kaen University.

\section{References}

Bénit-Gbaffou, C., \& Katsaura, O. (2014). Community leadership and the construction of political legitimacy: Unpacking Bourdieu's "Political capital" in post-apartheid Johannesburg. International Journal Urban Regional Research, 38, 1807-1832. https://doi.org/10.1111/1468-2427.12166

Berger, N. O. (n.d.) Needs assessment in human resource development. Human Resources and their Development, Vol.1 in Encyclopedia of Life Support Systems. Retrieved from Needs Assessment in Human Resource Development (eolss.net)

Boonchom, S. (2013). Preliminary research (9th ed.). Bangkok, Thailand: Suveeriyasan.

Martiskainen, M. (2017). The role of community leadership in the development of grassroots innovations. $\begin{array}{lllll}\text { Environmental Innovation and Societal Transitions, } & \text { 22(2017), }\end{array}$ https://doi.org/10.1016/j.eist.2016.05.002

Non-formal Education Commission ONFEC. (2005). Report on the supervision of the program of developing CLCs as life-long learning centers. Bangkok, Thailand: Education's Supervisor Unit

Office of the Promotion of Non-formal and Informal Education. (2012). Continuing educational management guide. Bangkok, Thailand: Rangsit printing.

Onyx, J., \& Leonard, J. R. (2011). Complex systems leadership in emergent community projects. Community Development Journal, 46, 493-510. https://doi.org/10.1093/cdj/bsq041

Pilcher, J. (2016). Learning needs assessment: Not only for continuing education. Journal for Nurses in 
Professional Development, 32(4), 185-191. https://doi.org/10.1097/NND.0000000000000245

Riley, K. (2012). Walking the leadership tightrope: Building community cohesiveness and social capital in schools in highly disadvantaged urban communities. British Educational Research Journal, 39, 1-21. https://doi.org/10.1080/01411926.2012.658021

Sullivan, H. (2007). Interpreting 'community leadership' in English local government. Policy Politics, 35, 141161. https://doi.org/10.1332/030557307779657775

U.S. Department of Education. (2018). $21^{\text {st }}$ century community learning centers. Retrieved from 21st Century Community Learning Centers (ed.gov)

Uhl-Bien, M., Marion, R., \& McKelvey, B. (2007). Complexity leadership theory: Shifting leadership from the industrial age to the knowledge era. Leadership, Q.18, 298-318. https://doi.org/10.1016/j.leaqua.2007.04.002

UNESCO office Bangkok and Regional Bureau for Education in Asia and the Pacific. (2008). Community learning centers: Country report from Asia. Bangkok, Thailand: UNESCO Asia and Pacific Regional Bureau for Education.

Zanbar, L., \& Itzhaky, H. (2013). Community activists' competence the contributing factors. Journal of Community Psychology, 41, 249-263. https://doi.org/10.1002/jcop.21527

\section{Copyrights}

Copyright for this article is retained by the author(s), with first publication rights granted to the journal.

This is an open-access article distributed under the terms and conditions of the Creative Commons Attribution license (http://creativecommons.org/licenses/by/4.0/). 